\title{
UNCERTAINTY ANALYSIS OF QUASI-TWO-DIMENSIONAL FLOW SIMULATION IN COMPOUND CHANNELS WITH OVERBANK FLOWS
}

\author{
HOSSIEN RIAHI-MADVAR ${ }^{1 *}$, SEYED ALI AYYOUBZADEH ${ }^{1)}$, \\ MASOUD MONTAZERI NAMIN ${ }^{2)}$, AKRAM SEIFI ${ }^{3)}$ \\ 1*)Department of Water Structures Engineering, Tarbiat Modares University, P.O.Box 14115-336, Tehran, Iran; \\ Mailto: hossien.riahi@gmail.com; ayyoub@modares.ac.ir \\ ${ }^{2)}$ Department of Civil Engineering, Tehran University, Tehran, Iran. \\ ${ }^{3)}$ Department of Irrigation and Drainage Engineering, Tarbiat Modares University, Tehran, Iran.
}

Flow in compound channels with overbank flows becomes more complex because of shear interactions between flows in main channel and flood plains, lateral momentum transfer and secondary flows. Compound channels have interesting applications in flood control, civil engineering and environmental management. Because it is difficult to obtain sufficiently accurate and comprehensive understandings of flow in natural compound rivers, the developed models of flow in overbank flows have many uncertainties. The main aims of this paper are to analysis and quantify the uncertainty results of quasi two dimensional flow modeling in compound channels. In this paper a quasi two dimensional depth averaged model, known as Shiono and Knight Model (SKM), in compound channel is used and uncertainty analysis of its simulation results is done based on Monte-Carlo simulations. Results indicated that although the SKM model can simulate quasi-two-dimensional flow accurately but it has many uncertainties in simulation results. The uncertainties of model results in high are greater than low flows. Also uncertainties in discharge capacity and shear stress are greater than those for velocity profiles. Overall results cleared that the SKM model, beyond from its strong physical basics, requires rigorous effort on local calibration processes, especially for high flood flows and these limit its global applicability and generalities.

KEY WORDS: Quasi-Two-Dimensional Flow, Compound Channels, Monte-Carlo, Overbank Flows, Uncertainty Analysis.

Hossien Riahi-Madvar, Seyed Ali Ayyoubzadeh, Masoud Montazeri Namin, Akram Seifi: ANALÝZA NEURČITOSTI SIMULÁCIE KVÁZI-DVOJROZMERNÉHO PRÚDENIA V KANÁLI SO ZLOŽENÝM PROFILOM A S PRÚDENÍM MIMO KORYTA. J. Hydrol. Hydromech., 59, 2011, 3; 17 lit., 12 obr. 3 tab.

Prúdenie vody $\mathrm{v}$ kanáli so zloženým profilom a s prúdením mimo koryta je javom zložitým, predovšetkým pre interakcie medzi prúdením v hlavnom toku a prúdením v zaplavenom území, ktoré spôsobujú laterálny transport momentu a sekundárne prúdenie. Zložené kanály sa často používajú najmä pri protipovodňovej ochrane, v stavitel'stve a v oblasti životného prostredia. Pretože je zložité získat' dostatok pesných informácií o prúdení vody v zložených korytách prirodzených tokov, existujúce modely prúdenia vody v zložených profiloch s mimobrehovým prúdením obsahujú vel’a neistôt. Cielom tohto príspevku je analýza a kvantifikácia neistôt vo výsledkoch simulácie kvázi-dvojrozmerného prúdenia v zloženom kanáli s prúdením mimo koryta. $\mathrm{V}$ tejto práci používame kvázi-dvojrozmerný vertikálne spriemerovaný model, známy ako model Shiona a Knighta (SKM) pre zložený profil. Analýza neurčitosti je realizovaná metódou Monte-Carlo. Výsledky naznačujú, že model SKM je schopný simulovat' kvázi-dvojrozmerné prúdenie pomerne presne, výsledky simulácií sú však značne neurčité. Tieto neistoty sú väčšie ako minimálne prietoky. Taktiež neurčitosti v prietokoch a v tangenciálnych silách sú väčšie ako neurčitosti pre rýchlostné profily. Celkovo výsledky ukazujú, že model SKM, nehladiac na jeho silný fyzikálny základ, si vyžaduje kalibráciu, predovšetkým pre vysoké prietoky, čo limituje rozsah jeho použitia.

KL'ÚČOVÉ SLOVÁ. kvázi-dvojrozmerné prúdenie, zložený profil kanála, Monte Carlo, prúdenie mimo koryta, analýza neurčitosti. 


\section{Introduction}

Nearly all of natural rivers have compound cross sections, where composed of a deep main channel and adjacent shallow floodplains. Compound channels exist widely in natural rivers, especially in alluvial streams. They differs from a single channel in the aspects of adjusting flood, cutting flood peak, transporting sediment, etc (Chatila, 1997; Abida and Ellouze, 2008). In low flows only the main channel conveys discharge of flow, but during periods of high flow, adjacent flood plains contribute in conveyance of flood in channel. In a channel with a compound section incorporating a flood plain, a strong interaction takes place between flows over the flood plain and within the main channel (Knight and Demetriou, 1983). The deep, fast flow within the main channel and the relatively shallow, slow flow over the floodplain take strong interactions. Theses interactions transfer longitudinal momentum between the two flow regions, decreasing flow velocity and boundary shear within the channel and increasing them over the flood plain. Furthermore compound channels have interesting applications in flood control, civil engineering and environmental management. In some cases, multi-stage channels are deliberately formed to increase the storage capacity in order to reduce the flood peak. The prediction of the conveyance capacity, velocity distribution, and boundary shear stress distribution is clearly important for flood management activities, bank protection and sediment transport in such channels and design of accurate flood defense schemes. To predict over bank flows flood level, in compound channels traditionally studies used subdivision techniques. These 1-D methods does not take into account the effects of momentum and mass transfer/interactions, secondary flows between the main channel and its floodplains, and are not accurate for compound channels.

A more refined method, based on a simple depthaveraged form of the stream wise Navier-Stokes equation is proposed by Knight and Brown, 2001; Knight et al., 2007 and is known as SKM. It has been shown that this model is capable to predict conveyance capacity of rivers with overbank flow better than other methods, as well as giving the lateral distributions of velocity and bed shear stress across the channel. This model have three calibration parameters of friction factor $(f)$ or Manning's roughness $n$, dimensionless eddy viscosity $(\lambda)$ and secondary current term $\left(\beta_{S}\right)$, that can vary from one case to another case and fitting the SKM results with observed values requires calibration of these parameters. The SKM accounts for bed shear, lateral shear, and secondary flow effects via these coefficients (Tang and Knight, 2008), so this meaningless physical calibration process increases the uncertainty in results of SKM.

Uncertainty of model parameters is one of the major uncertainty sources in model results. Although several calibration and case studies has been done on the SKM over past decade (Tang and Knight, 2008; Liao and Knight, 2008; Seckin et al., 2009; Unal et al., 2010; Webr and Menendez, 2004; Knight et al., 2007) but the uncertainty of its simulation results in prediction of velocity distribution, boundary shear stress and discharge capacity has not yet been studied. So, the main aim of this paper is to develop a framework for analyzing uncertainties of quasi-two-dimensional SKM, which are resulted from its global calibration. At first the accuracy of SKM in simulations is assessed and then uncertainty analysis of its simulations are investigated. An integrated approach of Monte-Carlo for all of SKM calibration parameters is developed and global calibration uncertainties of SKM are assessed. The paper is organized as follows. Section 2 deals with the theory and governing equations of SKM and its closure parameters. In Section 3 the used database in SKM validation and uncertainty analysis is discussed. In Section 4 the developed framework for uncertainty analysis of SKM based on Monte Carlo simulations is presented and finally in section 5 the study results are discussed.

\section{Quasi-two-dimensional SKM model}

The simplified form of Navier-Stokes equation for a fluid element in steady uniform flow, in which there are both bed generated shear and lateral shear, can be written in the following form (Unal et al., 2010):

$\rho\left[v \frac{\partial u}{\partial y}+w \frac{\partial w}{\partial z}\right]=\rho g \sin \theta+\frac{\partial \tau_{y x}}{\partial y}+\frac{\partial \tau_{z x}}{\partial z}$

i.e., secondary flows $=$ weight force + Reynolds stresses (lateral + vertical), where $u, v, w$ are the local velocities in the $x$ (stream wise), $y$ (lateral) and $z$ (vertical) directions respectively; $\operatorname{So}=\sin \theta-$ the bed slope; $\tau_{y x}$ and $\tau_{z x}$ - the Reynolds stresses on planes perpendicular to the $y$ and $z$ directions respectively; $\rho$ - the water density, and $g$ is the gravi- 
tational acceleration. Shiono and Knight (1989) obtained the depth-averaged velocity equation by integrating Eq. (1) over the water depth $H$ based on the eddy viscosity approach. Thus the SKM is a simple depth-averaged flow model which determines the lateral distribution of depth averaged velocity and boundary shear stress across river and channels. The quasi 2D SKM that take 3D effects into account has the following form (DEFRA/EA, 2002; Kordi et al., 2008):

$$
\begin{aligned}
& \rho g H S_{0}-\rho \frac{f}{8} U_{d}^{2} \sqrt{1+\frac{1}{s^{2}}}+\frac{\partial}{\partial y} \\
& \left\{\rho \lambda H^{2}\left(\frac{f}{8}\right)^{1 / 2} U_{d} \frac{\partial U_{d}}{\partial y}\right\}=\frac{\partial H(\rho U V)_{d}}{\partial y}
\end{aligned}
$$

where $H$ is depth of water in channel, $U_{d}$ and $V_{d}-$ depth averaged velocity components, $S_{0}$ - longitudinal bed slope, $f$ - friction factor, $s-$ channel side slopes and $\lambda$ - dimensionless eddy viscosity. Subscript ' $d$ ' signifies that the term is depth-averaged. In this study this equation is solved numerically using finite difference method in conjunction with Monte-Carlo simulations coded in MATLAB. The right hand side term of this equation takes for secondary flow effects and express as (DEFRA/EA, 2004):

$$
\frac{\partial H(\rho U V) d}{\partial y}=\beta_{s} \rho g S_{0} H
$$

where $\beta_{s}$ is the parameter of secondary flow and requires calibration process and for any subsection have different values. Its values for main channels generally used as 0.15 and for flood plains as -0.25 (DEFRA/EA, 2004). The following equation is presented by Abril and Knight (2004) for $\beta_{s}$ values in flood plains:

$\beta_{s f}=\beta_{s c}\left(-0.4+0.81\left(\frac{H_{f}}{H_{c}}\right)^{-0.8}\right) \frac{H_{c}}{H_{f}}$,

where the subscript $f$ refers to flood plain values and the subscript $c$ refers to main channel. The friction factor of $f$ is determined from Manning's roughness:

$$
f_{c}=\frac{8 \mathrm{~g} n_{c}^{2}}{R^{1 / 3}} .
$$

The subscript $c$ refers to main channel and $R$ is hydraulic radius of flow, $n$ - Manning's roughness as the second calibration parameter of SKM. The friction factor for flood plains is calculated by Ayyoubzadeh (1997):

$$
f_{f}=f_{c}\left(\frac{n_{f}}{n_{c}}\right)^{2}\left(0.669+0.331\left(\frac{H_{f}}{H_{c}}\right)^{-0.719}\right) \text {, }
$$

where the subscript " $f$ " refers to flood plain values and " $c$ " refers to main channel values. Another calibration parameter of SKM model is the dimensionless eddy viscosity $\lambda$ which for main channels set as 0.24 and for flood plains is calculated by Ayyoubzadeh (1997):

$$
\lambda_{f}=\lambda_{c}\left(-0.20+1.2\left(\frac{H_{f}}{H_{c}}\right)^{-1.44}\right) .
$$

Boundary shear stress in SKM model is calculated by Knight et al. (2007), Liao and Knight (2008):

$$
\tau_{b}=\left(\frac{f}{8}\right) \rho U_{d}^{2},
$$

where $\tau_{b}$ is local boundary shear stress and $U_{\mathrm{d}}-$ depth averaged velocity equals to (Liao and Knight, 2008):

$U_{d}=\frac{1}{H} \int_{0}^{H} u \mathrm{~d} z$.

Also shear velocity equals to: $U_{*}=\left(\tau_{b} / \rho\right)^{0.5}$. Discharge capacity in compound channels is calculated by integration of derived numerical values of depth averaged velocity (from Eq. (2)) over total width of channel. Lateral velocity distributions are computed by numerical solution of Eq. (2) using finite difference method with non-slip boundary conditions for walls. As mentioned in previous equations, the SKM have three calibration parameters of $n, \lambda, \beta_{s}$ which should be calibrated for calculation of conveyance capacity, shear and velocity distributions. In this paper the authors have collected a database of velocity distribution and conveyance in compound channels from Ayyoubzadeh (1997) and corresponding values of these calibration parameters in main channels. Finally the Monte-Carlo simulation approach is used for uncertainty analysis of SKM calibration parameters and assessed their effects on model results. 


\section{Database and uncertainty analysis}

In this study two types of data are used for SKM validation and uncertainty analysis. One is used for validating velocity, shear stress distributions and conveyance estimation and the other is used for uncertainty analysis of calibration parameters. Most of these data are collected form experimental works carried out by HR Wallingford in England in compound channel flumes with large-scale facility (Ayyoubzadeh, 1997). Also, some of field data were collected from natural of Severn at Montford Bridge (Ayyoubzadeh, 1997). The ranges of geometric and hydraulic characteristics of collected data on compound channels, which are used in conveyance estimation and uncertainty analysis of SKM, are listed in Tab. 1. Lateral stream wise velocity distribution in rectangular compound channels are obtained from Chatila (1997). He has presented measurements of lateral distribution of depth averaged longitudinal velocity in a symmetric compound flume, which only have one left flood plain. Also another data set of lateral velocity and boundary shear stress distributions in a large scale trapezoidal symmetry compound channel of SERC-FCF is used for large scale floodplain (Ayyoubzadeh, 1997).

$\mathrm{T} \mathrm{a} \mathrm{b} 1 \mathrm{e} 1$. Range of geometric and hydraulic variables used in conveyance uncertainty analysis.

\begin{tabular}{cc}
\hline Variable & Range \\
\hline Bank full height & $0.031-6[\mathrm{~m}]$ \\
Main channel width & $0.152-21.4[\mathrm{~m}]$ \\
Floodplain width & $0-63[\mathrm{~m}]$ \\
Main channel side slope & $0-2$ \\
Floodplain side slope & $0-7.1$ \\
Manning's roughness & $0.01-0.05$ \\
Bed slope & $0.000185-0.005$ \\
Flow depth & $0.036-7.81[\mathrm{~m}]$ \\
Discharge & $0.003-3.5\left[\mathrm{~m}^{3} \mathrm{~s}^{-1}\right]$ \\
\hline
\end{tabular}

\section{Framework for uncertainty analysis using Monte-Carlo simulations}

There are three major sources of uncertainty in the outputs of a model: structural uncertainty, input uncertainty and parameter uncertainty. The structural uncertainty stems from adopting a set of assumption to simplify the modeling of the desired process. The uncertainty in input and model parameters are induced respectively by the error in model inputs and errors related to the non-uniqueness sets of model parameters and governing mathematics (Abbaspour et al., 2007; Riahi and Ayyoubzadeh,
2010). In this study uncertainty analysis of SKM parameters are investigated using a Monte-Carlo (MC) simulation. The conventional MC simulation approach has three steps: 1. randomly sampling by considering the probability distribution of the investigated variables; 2 . Entering the combination of all of random samples into the model and run model simulations iteratively; and 3. statistically and graphically analyzing the output results of model to quantify its uncertainties. This method is conceptually simple, theoretically sound, and flexible and it can handle both small and large uncertainties in input quantities. To achieve the aims of this study, the probability distribution of calibration parameters are determined and then by using corresponding probability distribution a large set of random calibration parameters is generated and they are implemented in SKM. Finally results of SKM runs are assessed graphically and statistically to quantify model uncertainties. Therefore, a database of three calibration parameters of SKM is used for the Monte-Carlo sample generations. For comparison of SKM velocity and shear distributions with observed values, observed profiles in rectangular and trapezoidal compound channels are used. In uncertainty analysis the corresponding probability distributions of parameters of $\lambda, n$ and $\beta_{s}$ are determined and after that by random number generation, $2^{14}=$ $=16384$ random samples of these parameters are generated. These samples were feeded to the SKM model and its outputs in form of velocity and shear distribution and discharge capacity are calculated numerically. The output results of SKM are calculated by numerical solving of Eq. (2) with closure coefficients using finite difference method coded in MATLAB and combined with Monte-Carlo simulations.

Uncertainty results of SKM model are presented graphically as confidence interval over observed values. The $95 \%$ confidence intervals are determined by finding the $2.5^{\text {th }}$ and $97.5^{\text {th }}$ percentiles of the constructed distribution. This is calculated by the $2.5^{\text {th }}(\mathrm{XL})$ and $97.5^{\text {th }}(\mathrm{XU})$ percentiles of the cumulative distribution of every simulated point. The goodness of fit is assessed by the uncertainty measures calculated from the percentage of measured data bracketed by the 95PPU band, and the average distance $\bar{d}_{x}$ between the upper and the lower 95PPU band (or the degree of uncertainty). Finally the d-factor is determined as: 
$\bar{d}_{x}=\frac{1}{k} \sum_{l=1}^{k}\left(X_{U}-X_{L}\right)$

$d-$ factor $=\frac{\bar{d}_{x}}{\sigma_{x}}$

where $k$ is the number of observed data points, $\sigma_{x}$ - the standard deviation of the measured variable $X$. The best outcome is that $100 \%$ of the measurements are bracketed by the 95PPU, and $d$-factor close to zero. The magnitude of $d$-factor is directly related to the amount of uncertainty in the simulated outputs, the larger the $d$-factor, the larger the uncertainty. A value of $d$-factor $<1$ is a desirable measure for the $d$-factor. The percentage of data bracketed in $95 \%$ confidence interval is calculated as:

Bracketed by $95 P P U(\%)=$

$$
=\frac{\operatorname{Count}\left(Q \mid, X_{L} \leq Q \leq X_{U}\right)}{n} \times 100 \text {. }
$$

\section{Results and discussion}

In this section the accuracy and uncertainty results of SKM parameters are presented. The results are presented in three sections: At first the SKM results are compared with observed values, next the uncertainty results in discharge capacity of compound channels and finally uncertainty results of SKM for velocity and shear distributions are presented.

\subsection{Accuracy analysis of SKM results}

In this section the results of SKM in comparison with observed values of velocity, shear stress and discharge capacity are presented. These results obtained through a trial an error calibration process, in which the initial values of $\beta_{s}, \lambda$ were 0.15 and 0.24 respectively. In Fig. 1 velocity profile obtained from calibrated SKM is compared with observed values in a rectangular compound channel. In Fig. 1 the final values of calibration parameters derived as $\beta_{s c}=0.69 ; \beta_{s f}=-0.05 ; \lambda_{c}=0.24 ; n=0.014$. The SKM results for trapezoidal large scale compound channel in terms of lateral velocity distribution and shear stress are shown in Figs. 2-3. In these Figs. the calibrated values derived as: $\beta_{s c}=0.27 ; \beta_{s f}=$ $-0.25 ; \lambda=0.7 ; n=0.008863$. According to the results in Fig. 1, it's clear that the calibrated SKM has good capabilities in prediction of lateral velocity profile of depth average velocity and accurately can predict strong velocity gradients between main channel and flood plains. There are minor discrepancies between SKM and observed values near the floodplain bank and main channel bank, where there are steep gradients in velocity profiles. It is noticeable that in this experiment the observed discharge was measured as: $0.068 \mathrm{~m}^{3} \mathrm{~s}^{-1}$ while the SKM predicted it as $0.065 \mathrm{~m}^{3} \mathrm{~s}^{-1}$. In Fig. 2 the results of calibrated SKM are compared with observed velocity profile in a large scale trapezoidal compound channel, again calibrated model results are very close to observed values. In Fig. 3 the local boundary shear stress predicted by calibrated SKM are compared with observed values. By comparing results in Fig. 1 with those in Fig. 2, it is concluded that SKM have more accuracy in trapezoidal compound channels than rectangular ones. This is because of small gradients in trapezoidal channel near banks than those in rectangular ones. Although, results in Figs. 1-3 indicate that the calibrated SKM can accurately predict lateral velocity and shear stress in compound channels, but the final values of calibration parameters in SKM have significant effects on velocity and shear stress distributions and those values vary diversely from one case to another case and this is the major deficiency of SKM.

In Figs. 4 and 5 the results of SKM in discharge calculations are compared with observed values of 440 data points of FCF. As the SKM calibrated parameters are case dependent, in discharge calculations, the default values of $\beta_{s}$ and $\lambda$ are used, i.e. $\beta_{s c}=0.15 ; \beta_{s f}=-0.25 ; \lambda_{c}=0.24$. In Figs. 4 and 5 the goal was to asses the SKM results in comparison with observed values of stage-discharge relations using default values of its parameters. Based on the results in Figs. 4 and 5, the SKM under predicts the discharge capacity of compound channels. Under predictions in flood discharge are equal to over predictions in flood stages in Fig. 5. Using default values of SKM parameters is resulted in RMSE $37.45 \mathrm{~m}^{3} \mathrm{~s}^{-1}$ and $\mathrm{R}^{2} 0.823$ in discharge calculations. From the results in Fig. 4 it's concluded that the SKM has more accuracy in low flows, especially in experimental flumes, but it has poor predictions in high flows and in field scales. In Fig. 5 the stage-discharge curve of compound channels predicted by SKM are compared with observed values. From this Fig. it is declared that SKM in field observations and high flood flows, with stages greater than $2 \mathrm{~m}$, have poor predictions. The pre- 


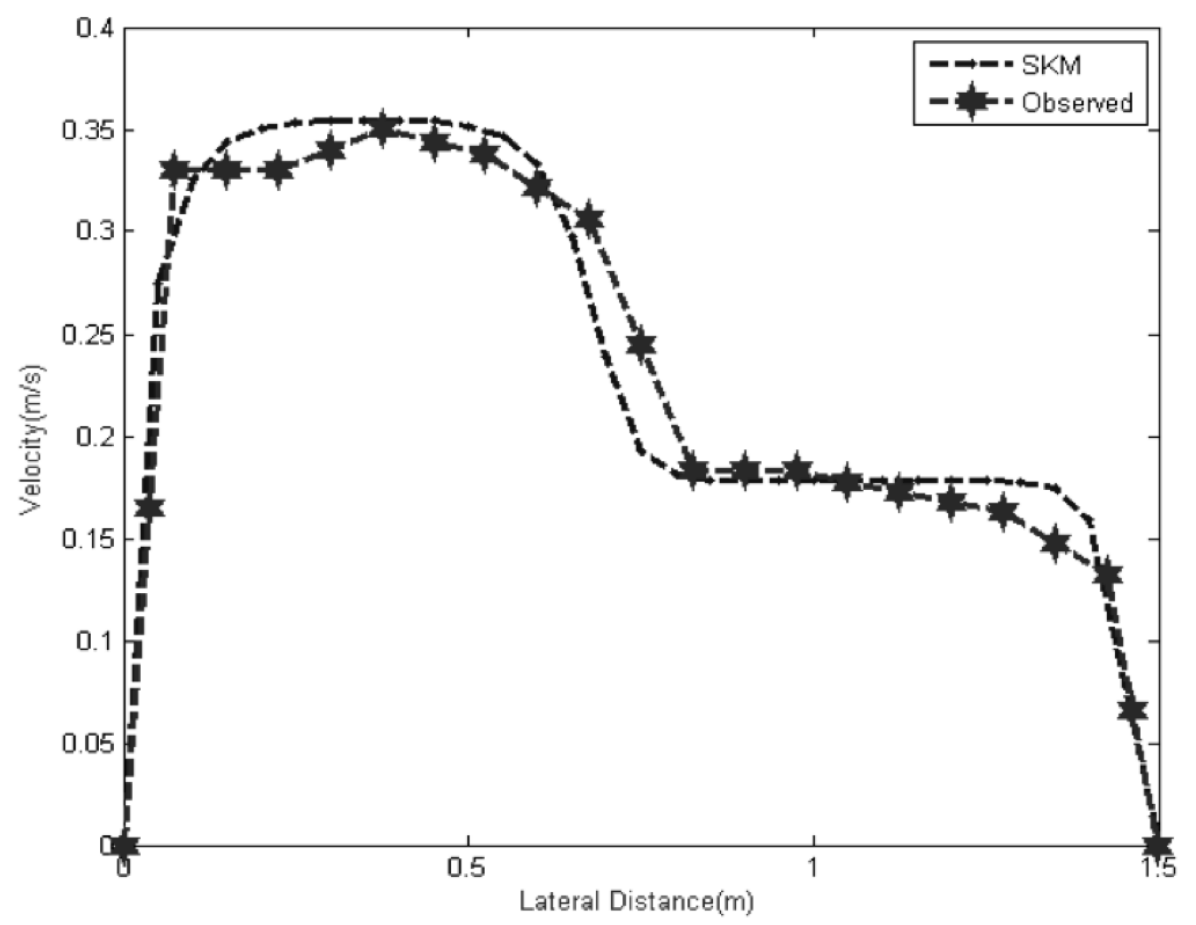

Fig. 1. Depth averaged velocity profile in an rectangular compound channel in comparison with observed values of Chatila (1997) $\left(\beta_{s c}=0.69 ; \beta_{s f}=-0.05 ; \lambda_{c}=0.24 ; n=0.014\right)$.

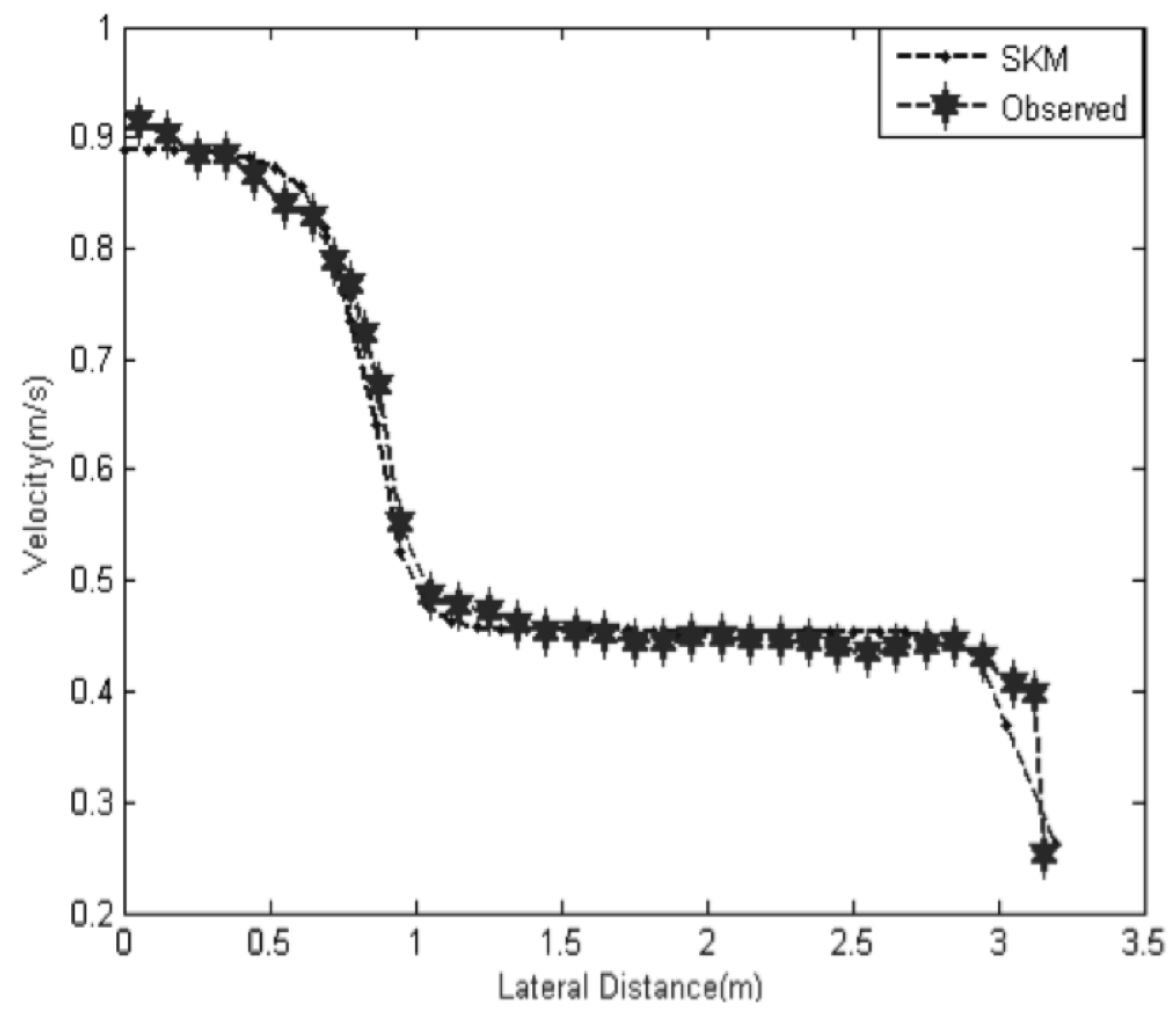

Fig. 2. Depth averaged velocity profile in a large scale trapezoidal compound channel in comparison with observed values of $\operatorname{SERC}-\mathrm{FCF}\left(\beta_{s c}=0.27 ; \beta_{s f}=-0.25 ; \lambda=0.7 ; n=0.008863\right)$. 


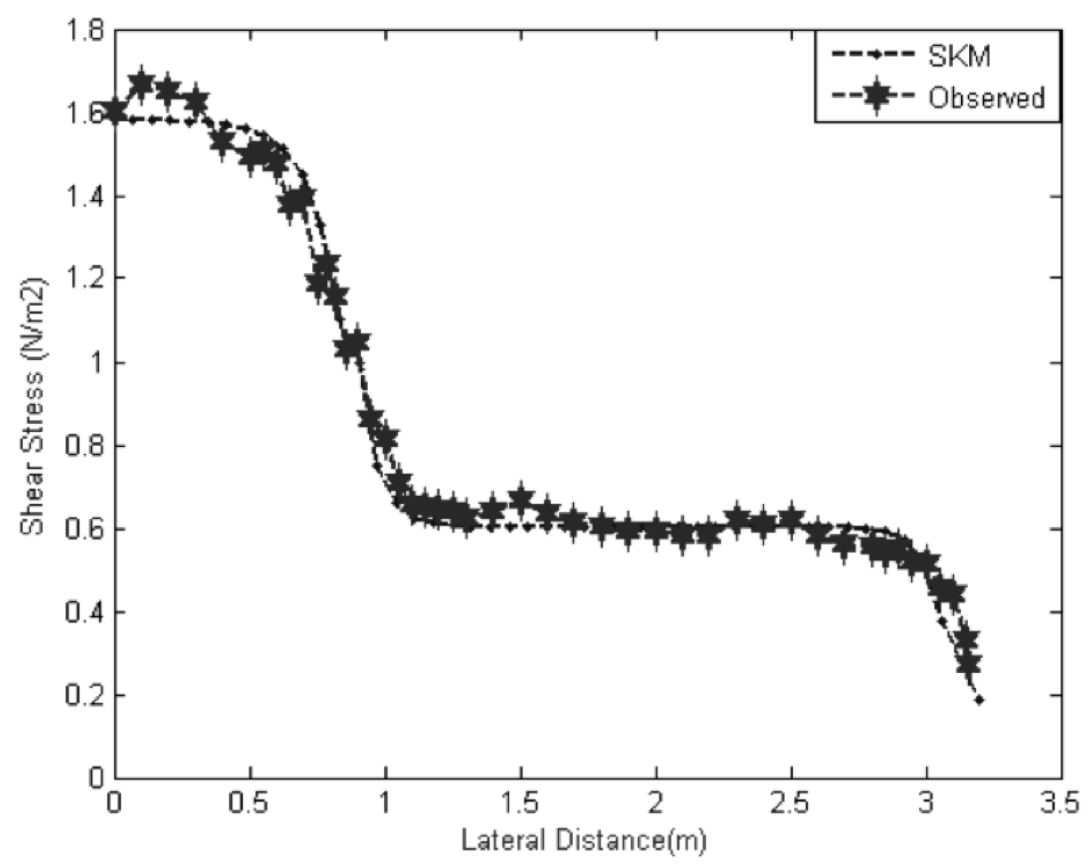

Fig. 3. Depth averaged shear stress profile in a large scale trapezoidal compound channel in comparison with observed values of SERC-FCF $\left(\beta_{s c}=0.27 ; \beta_{s f}=-0.25 ; \lambda=0.7 ; n=0.008863\right)$.

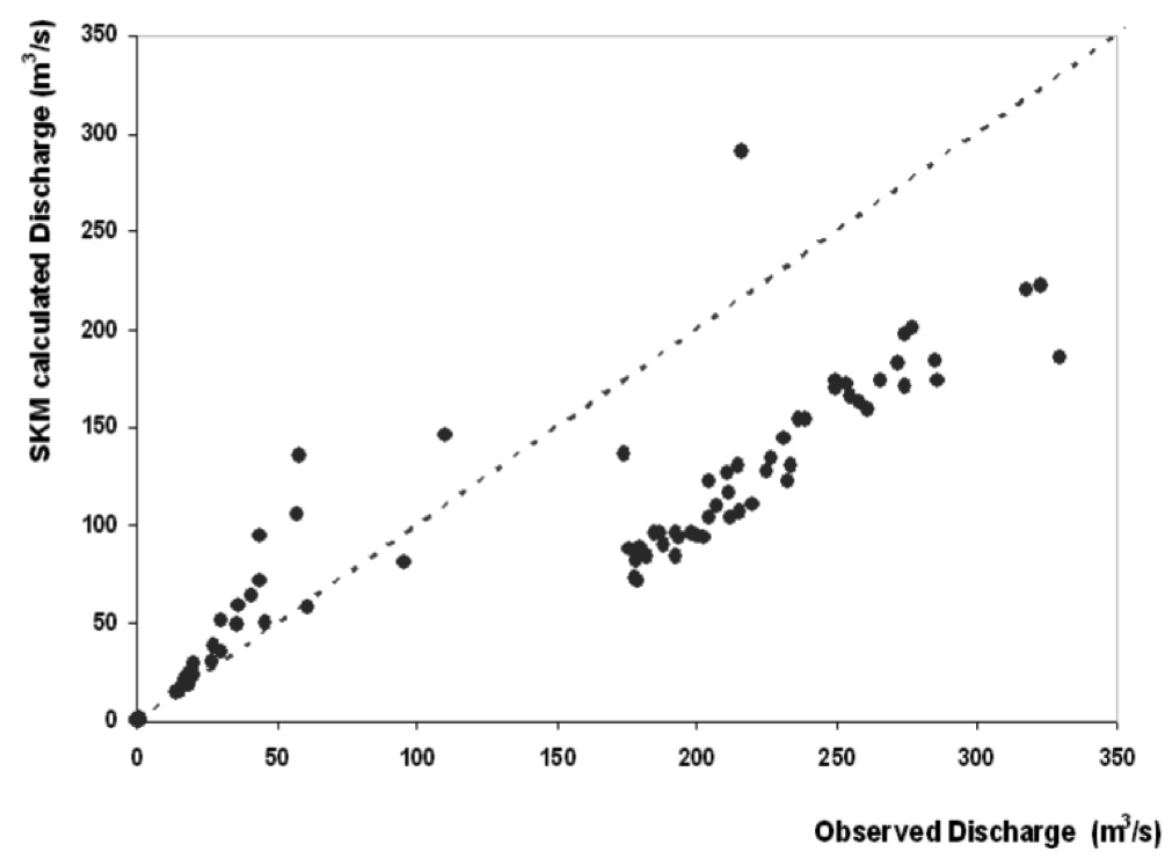

Fig. 4. Observed values of discharge in comparison with predicted values by SKM.

sented results in Figs. of 1-5 show that although calibrated SKM can accurately predict lateral velocity and shear stress profiles, but using default values of its parameters, cause poor estimates of discharge in compound channels and it produces more uncertainties in SKM results.
In order to investigate the effects of $\beta_{s}$ and $\lambda$ calibrations (as global values) on accuracy of discharge predictions in SKM, a loop is used in numerical model. In the computational loop, these parameters are varied from -2 to 2 and 0 to 2 respectively, by step of 0.1 and the SKM is implemented for all of 440 measured discharges and 
RMSE and $\mathrm{R}^{2}$ values of predictions are calculated and optimal values of $\beta_{s}$ and $\lambda$ in main channel are derived. The values of $\beta_{s}, \lambda$ and $f$ in floodplains are calculated using Eq. (4), (6) and (7) respectively. In Figs. 6 and 7 the variations of RMSE and $\mathrm{R}^{2}$ with changes in $\beta_{s}$, and $\lambda$ are presented respectively. Based on the results in Figs. 6 and 7 the optimal values of SKM parameters are derived as: $\lambda=0.3$ and $\beta_{s}=-0.75$, associated with RMSE minimum. As is shown in Figs. 6 and 7, changes in RMSE and $\mathrm{R}^{2}$ values of SKM predictions with its calibration parameters, show that its results are very sensitive to its calibration parameters and it is declared that the SKM discharge predictions have major limitations. These poor performances shows that using the SKM in field measurements and flood capacity prediction models, require rigorous case based considerations and we can't propose constant values for its parameters as default values of SKM parameters. Because of these different trends in SKM results from experiment to field measurements, the discharge capacity data are divided into two types of experimental and field, and then uncertainties analysis is done on them separately. The uncertainty results are presented in next section.

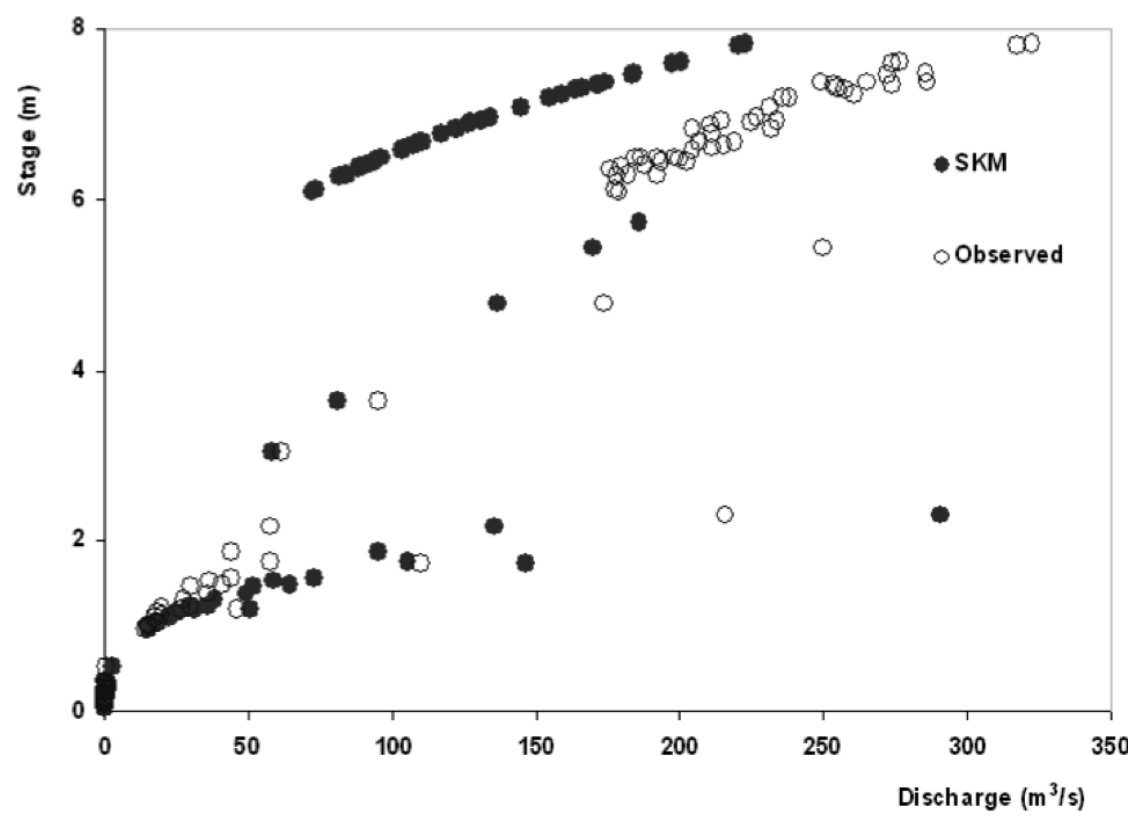

Fig. 5. Stage-discharge predicted by SKM and observed values.

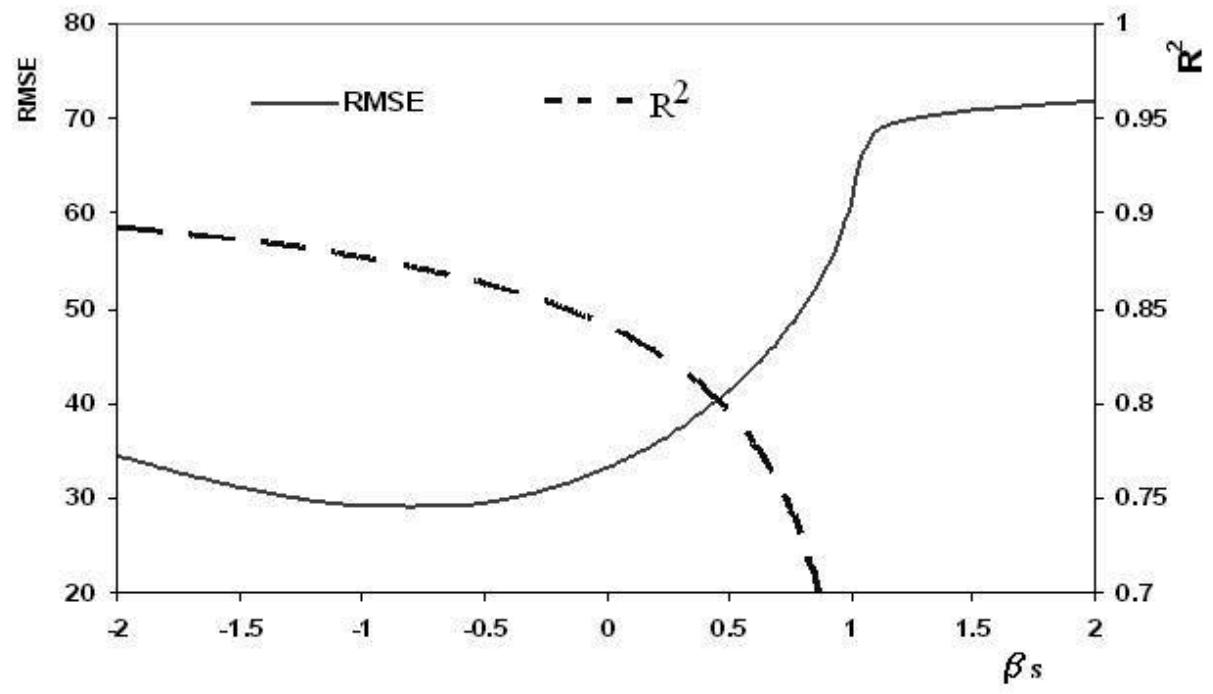

Fig. 6. Effects of $\beta_{s}$. Variations on accuracy of SKM discharge predictions. 


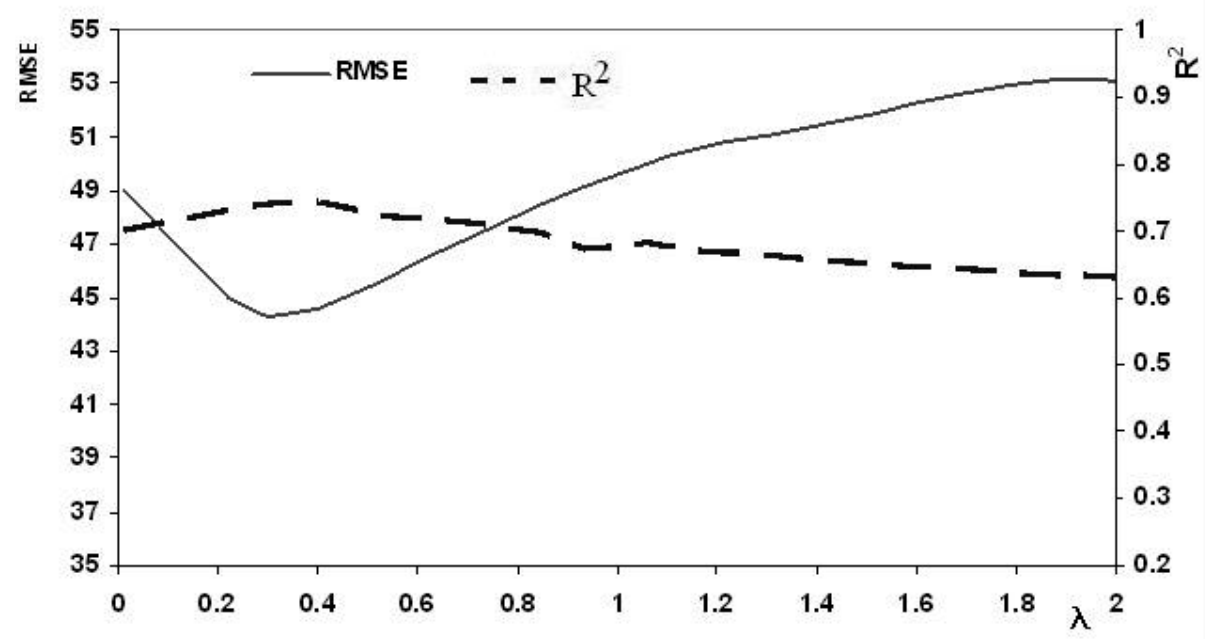

Fig. 7. Effects of $\lambda$ variations on accuracy of SKM discharge predictions.

\subsection{Uncertainty results of discharge capacity}

In this section the uncertainty results of SKM calibration parameters for discharge capacity are presented in field and experimental measurements separately. It is required to generate random samples of parameters by using probability distribution of each parameter. The probability distribution of three calibration parameters of SKM and their statistical values of mean, maximum and minimum values are presented in Tab. 2. In this table the probability distribution of calibration parameters are determined using Kolmogorov-Smirnov test. In this table the Default M.C. shows default values of SKM model parameters, which are proposed by (DEFRA/EA, 2004) for a conveyance estimation system. In this table the presented parameters are for main channel. And those for floodplains are calculated by ratio equations (Eqs. 4-7). After random sample generation of calibration parameters, the uncertainty results of model are calculated based on the developed framework in section 4.

At firs the uncertainty results of low flows with discharge capacity lower than $1.11 \mathrm{~m}^{3} \mathrm{~s}^{-1}$ are presented in Fig. 8. The 95\% confidence intervals are determined by finding the $2.5^{\text {th }}$ and $97.5^{\text {th }}$ percentiles of associated distribution in simulation results. In Fig. 8 the SKM 95PPU bounds are grey bounds and the observed values have black lines. These results obtained from $2^{14}=16384$ random samples of calibration parameters, which are generated from their corresponding probability distributions given in Tab. 2. Also the statistical indices of SKM uncertainty results for all of investigated cases are presented in Tab. 3. In Fig. 9 the uncertainty bounds of
SKM for field discharges are presented. The results of SKM in Figs. 8 and 9 and in Tab. 3 show that it has some uncertainties in both field and experimental discharges. Although the well calibrated SKM has good predictions of velocity profile and discharge capacity in low flows (based on the results in Figs. 1-3) but it has extensive uncertainties in discharge capacity. The model uncertainties in field observations are very strong and show that using this numerical model for global cases of conveyance estimation requires significant consideration and effort on calibration processes and this limits its generalities. In order to asses the global uncertainties of SKM, the associated probability distribution of calibration parameters are determined based a global data set of field and experimental observations. The major uncertainties of SKM in a global assessment framework show that it is not acceptable to provide unique values of SKM calibration parameters as defaults. So using the SKM as a prediction tool of flood capacity in compound channels requires very careful calibration.

Another notice is that, based on the results of Bracketed by 95 PPU (\%) in Tab. 3, the PPU cover off for discharge capacity in field is $50 \%$ and in experiment is $37 \%$. This shows that the model formation isn't so well and it isn't suitable for capacity estimation in compound channels. The $d$-factors of SKM in Tab. 3 are close to 1 . By comparing $d$ factor values with $95 \mathrm{PPU}$ it is concluded that the model formation isn't proper for using as a global system conveyance estimation without considering local and case based calibration of its parameters (same as results in Figs. 6 and 7). 
$\mathrm{T} \mathrm{a} \mathrm{b} 1$ e 2. Probability distribution and range of three calibration parameters.

\begin{tabular}{ccccccc}
\hline Parameter & Distribution & Max & Mean & Min & Std. & Default M.C. \\
\hline$\lambda_{\mathrm{c}}$ & Gamma & 5.887 & 1.4971 & 0.07 & 1.5459 & 0.24 \\
$\beta_{s c}$ & Normal & 0.766 & 0.428 & 0.08 & 0.184 & 0.15 \\
$n_{c}$ & Normal & 0.028 & 0.0157 & 0.01 & 0.00433 & - \\
\hline
\end{tabular}

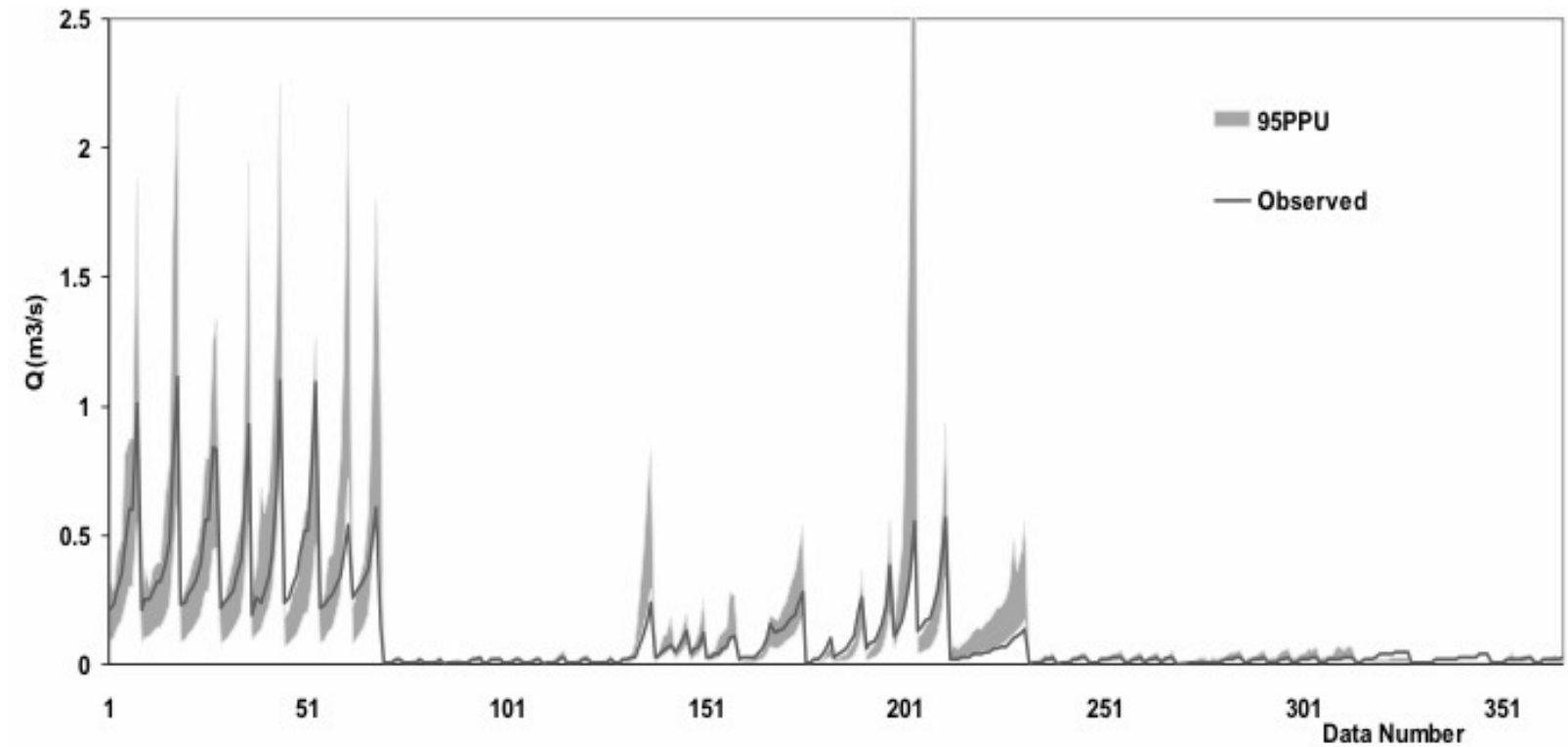

Fig. 8. Uncertainty results of SKM model for discharge capacity in low flows (flume).

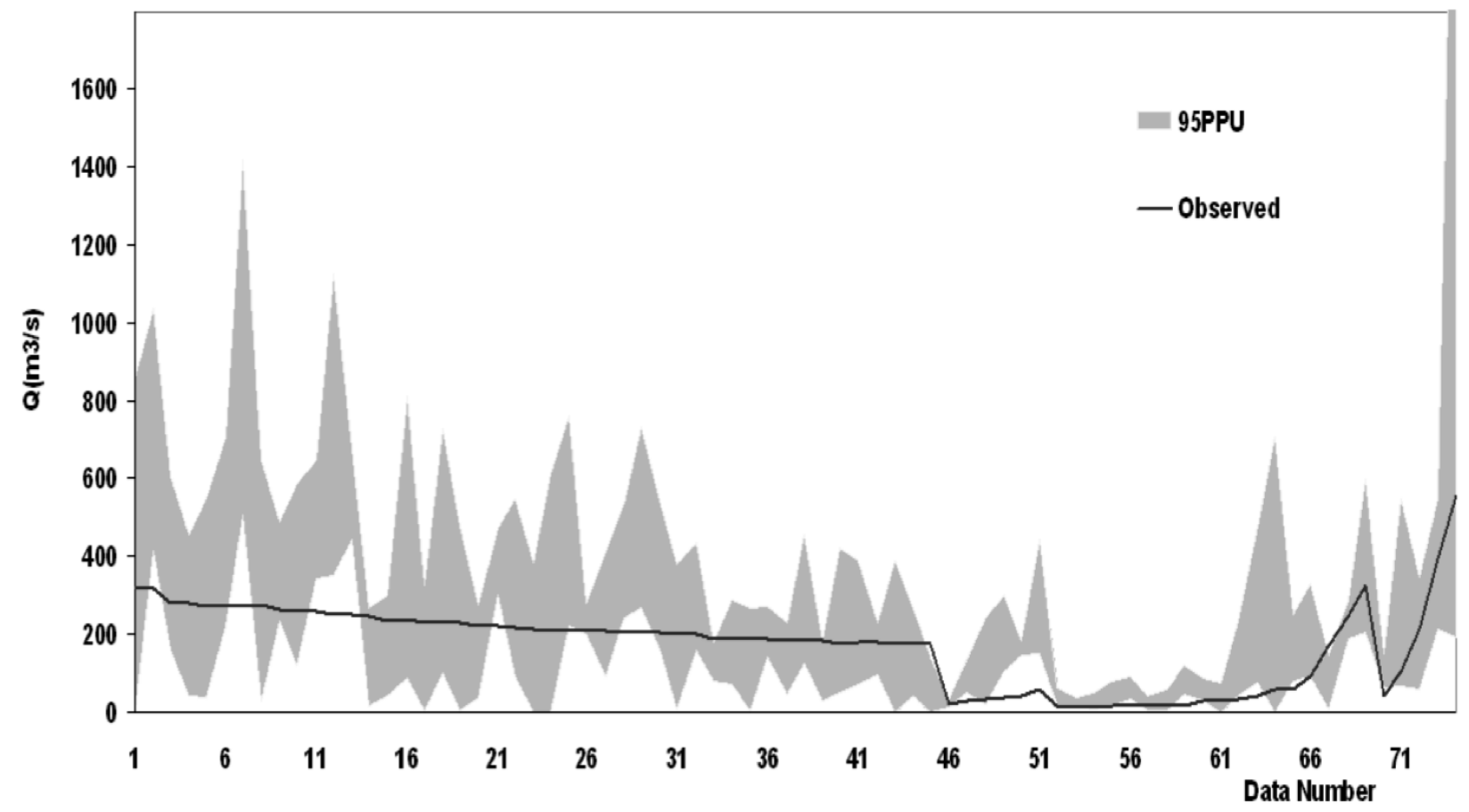

Fig. 9. Uncertainty results of SKM model for discharge capacity in high flows (field). 


\subsection{Uncertainty results of velocity and shear stress profiles}

The uncertainty results of velocity profile are done for rectangular compound flume experiments of (Chatila et al., 1997) and trapezoidal compound section of FCF. In Fig. 10 the uncertainty result of SKM for rectangular small scale channel are presented and those for large scale trapezoidal compound channel are presented in Fig. 11. From these Figs. It is declared that the SKM has strong uncertainty bounds for lateral velocity profiles in small and large scale channels. These Fig. show that the SKM uncertainty bounds for centerline of main channel, interaction zone of main channel with flood plains and in flood plains are lager than other regions. Also in flood plains, where the flow velocity is very low, the model lower uncertainty bounds are resulted in zero values and this is because of high standard deviation in generated samples and sensitivity of SKM velocity profiles to calibration parameters.

The 95PPU and $d$-factor values of velocity profiles are given in Tab. 3. This table show that the SKM velocity profiles are bracketed by confidence bounds fully but model has $d$-factors greater than 1 and shows its uncertainties comes from global calibration also based on the results which are presented in Tab. 3. It is concluded that the uncertainty bounds of SKM has covered 100 percents of observed values and this shows that the SKM greatly models the mathematical and physical background of two dimensional flow in compound channels (PPU $=100 \%)$. But the $d$-factor of examined cases is greater than 1 and this shows that the uncertainties in simulations of model are resulted from its global calibration parameters and it requires rigorous and accurate local calibration.

The uncertainty results of shear stress profiles are presented in Fig. 12 and in Tab. 3. Uncertainty bounds of shear stress profile are very extensive than those for velocity profiles and discharge capacities. Also the 95PPU of shear stress profiles in Tab. 3 is little than $100 \%$ and the $d$-factor of it is 11.78 and are very greater than other outputs. These great uncertainties in shear stress profiles specifically comes from double uses of $n$ Manning or friction factor calibration parameter and indicates that the SKM results are very dependent on model calibration processes and this limits the general applicabilities of SKM as a global and general conveyance estimation tool. Based on the overall uncertainty results of SKM it is concluded that using SKM needs a case based calibration process. Using constant values for its parameters, as default values, will generate major uncertainness in simulation results.

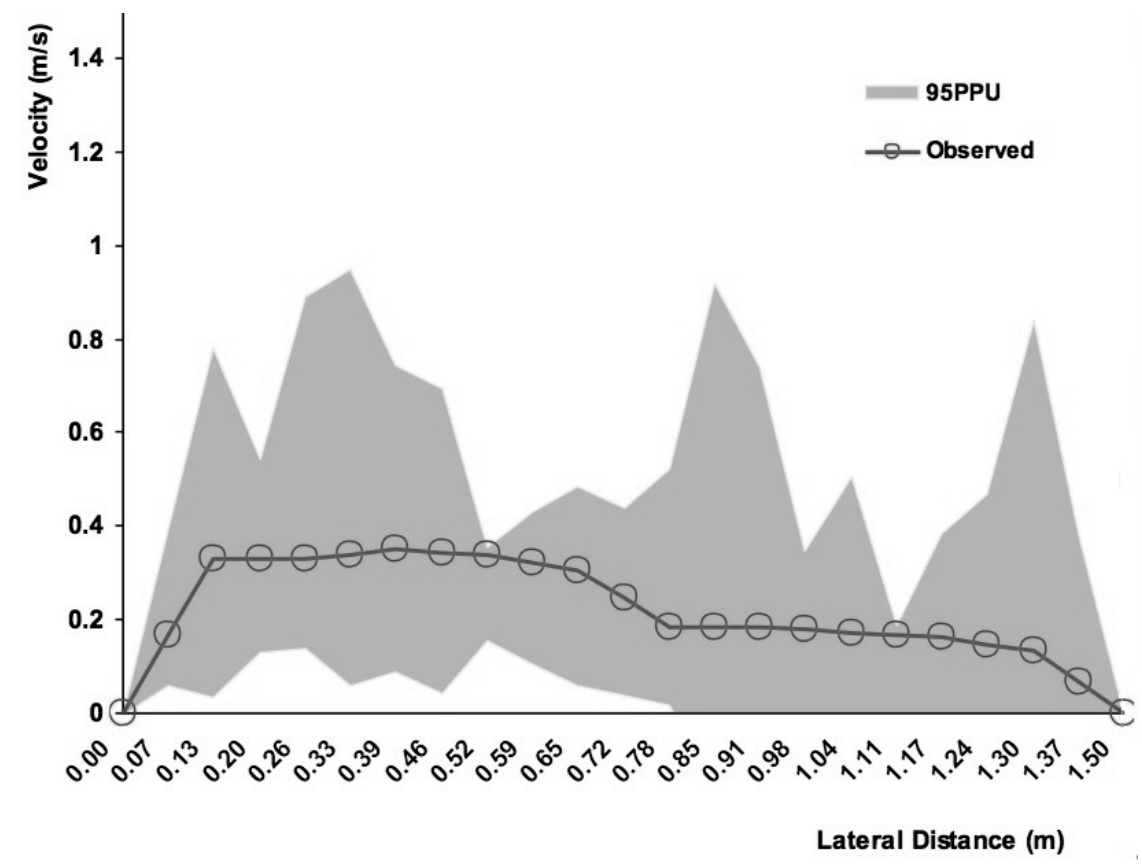

Fig. 10. Uncertainty results of SKM model for lateral velocity profile in rectangular compound channel. 


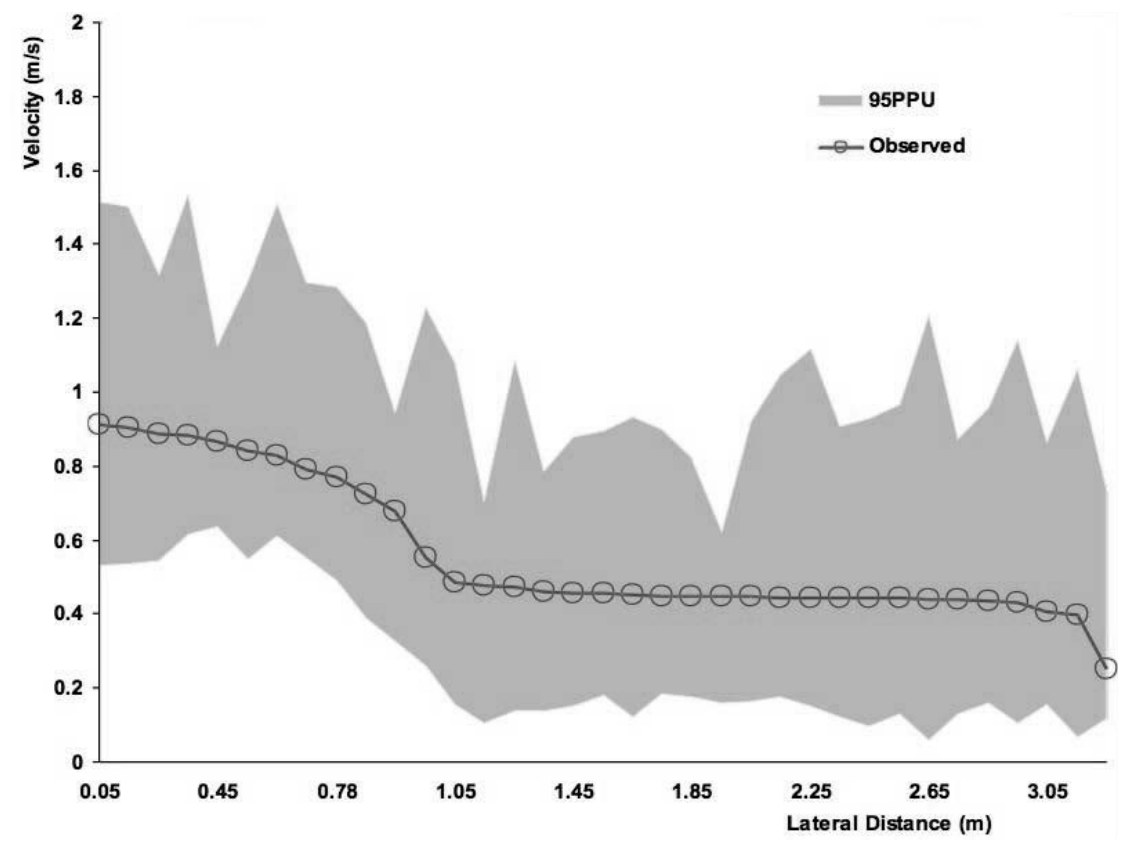

Fig. 11. Uncertainty results of SKM model for lateral velocity profile in large scale trapezoidal compound channel.

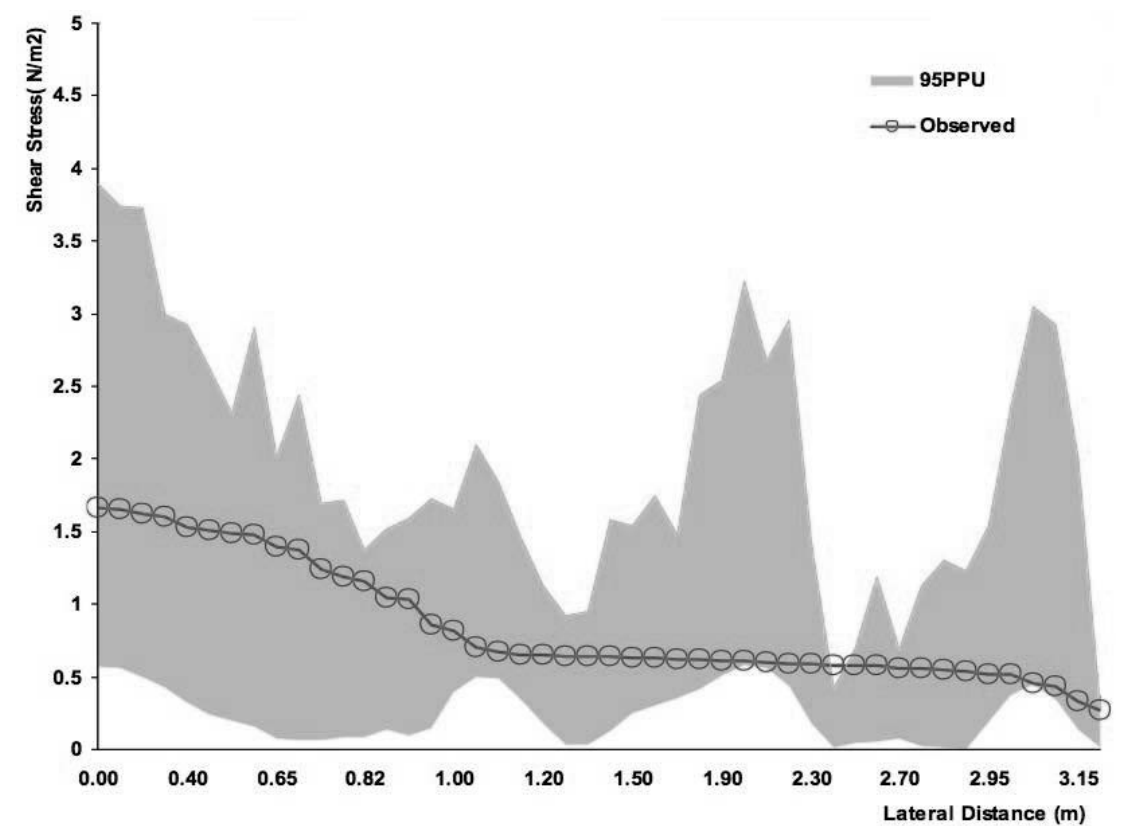

Fig. 12. Uncertainty results of SKM model for shear stress profile in large scale trapezoidal compound channel.

$\mathrm{T}$ a b l e 3. Uncertainty indices of SKM results.

\begin{tabular}{ccccccc}
\hline \multirow{2}{*}{ Indices } & \multicolumn{5}{c}{ Output Variable } \\
\cline { 2 - 6 } & \multicolumn{2}{c}{ Discharge } & \multicolumn{2}{c}{ Velocity Profile } & Shear stress \\
\cline { 2 - 6 } & Field & Experiment & Rectangular & Trapezoidal & Trapezoidal \\
\hline$d$-factor & 1.7 & 0.88 & 2.56 & 1.98 & 11.78 \\
Bracketed by 95 PPU [\%] & 50 & 37 & 100 & 100 & 97.83 \\
\hline
\end{tabular}




\section{Conclusions}

In this paper the authors used Monte-Carlo simulations for uncertainty analysis of quasi-twodimensional flow in compound channels. The well known simple model of Shiono-Knight (Knight et al., 2007) known as SKM model is used. This model is a simple depth averaged version of NavierStockes equations. Based on the results of accuracy and uncertainty analysis, although the calibrated SKM have good predictions of velocity and shear stress profiles, but for discharge estimations the SKM have some errors. For low flow the SKM have overestimates in flood discharge and for high flows it has underestimates. Sensitivity analysis of SKM discharges on $\beta_{s}$ and $\lambda$ has shown that we can't use constant values for model parameters as default values and they are case dependent values. Uncertainty results have shown that the SKM has very great uncertainties in its outputs in forms of velocity, shear profiles and discharge. The uncertainties for shear stress is greater than velocity and discharge, for velocity profiles its uncertainties are little than discharge and shear stress. High values of 95PPU in model outputs indicates that it has strong physically basis but higher $d$-factor and uncertainty bounds shows its limitations in forms of global calibration parameters. High uncertainty results observed in model results shows that SKM model results requires rigorous calibration processes for parameters of secondary flow, roughness and eddy viscosity. Based on the uncertainty results, the SKM results are very dependent on model calibration processes and this limits the general applicabilities of model as global and general conveyance estimation.

\section{REFERENCES}

ABBASPOUR K.C., YANG J., MAXIMOV I., SIBER R., BOGNER K., MIELEITNER J., 2007: Modeling hydrology and water quality in the pre-alpine/alpine Thur watershed using SWAT. J. Hydrol., 333, 413-430.

ABIDA H., ELLOUZE M., 2008: Lateral Momentum Transfer Effects in the Modelling of Unsteady Flows in Compound Channels. J. Hydrol. Hydromech., 56, 4, 228-236.

ABRIL J.B. and KNIGHT D.W., 2004: Stage-discharge prediction for rivers in flood applying a depth-averaged model. J. Hydraul. Res., IAHR, 122, 6.
AYYOUBZADEH S.A., 1997: Hydraulic aspects of straightcompound channel flow and bed load sediment transport. $\mathrm{PhD}$ Thesis, The University of Birmingham, U.K.

CHATILA J.G., 1997: Modeling of pollutant transport in compound open channels. [Ph.D. Thesis.] Civil Engineering Department. University of Ottawa, Ottawa, Ontario.

DEFRA/EA 2004: Reducing Uncertainty in River Flood Conveyance, Interim Report 3: Testing of Conveyance Methods in 1D River Models, Project W5A-057, HR Wallingford Ltd., United Kingdom.

KNIGHT D.W. and DEMETRIOU J.D., 1983: Flood plain and main channel flow interaction. J. Hydraul. Div., ASCE, 109, 8, 1073-1092.

KNIGHT D.W., OMRAN M., and TANG X., 2007: Modelling depthaveraged velocity and boundary shear in trapezoidal channels with secondary flows. J. Hydraul. Eng., 133, 10, 39-47.

KNIGHT D.W, BROWN F.A., 2001: Resistance studies of overbank flow in rivers with sediment using the flood channel facility. J. Hydraul. Res., 39, 283-301.

KORDI E., ABUSTAN I., ALAGHEMAND S., 2008: Prediction of Subsection Flow Regimes in Compound Channel. International Conference on Water Resources and Environmental Engineering, ICCBT 2008-D-(05), pp. 49-62.

LIAO H., KNIGHT D., 2008: Analytic Stage-Discharge Formulas for Flow in Straight Prismatic Channels. J. Hydraul. Engng., Vol. 133, No. 10, 1111-1122.

RIAHI H., AYYOUBZADEH S.A., 2010: Uncertainty analysis of ANN and ANFIS techniques in comparison with regime equations for determining regime channel geometry. Fifth International Conference on Water Resources and Environment Research 5th - 7th of July, 2010 at Quebec City, Canada.

SECKIN G., MAMAK M., ATABAY S., OMRANM M., 2009: Discharge estimation in compound channels with fixed and mobile bed. Sadhana, Vol. 34, Part 6, December, pp. 923-945.

SHIONO K, KNIGHT D.W., 1989: Two dimensional analytical solution compound channel. In: Proceedings of 3rd international symposium on refined flow modeling and turbulence measurements. Universal Academy Press. p. 591-599.

TANG X., KNIGHT D., 2008: Lateral Depth-Averaged Velocity Distributions and Bed Shear in Rectangular Compound Channels. J. Hydraul. Engng., Vol. 134, No. 91, 1337-1342.

UNAL B., MAMAK M., SEKIN G. and COBANER M., 2010: Comparison of an ANN approach with 1-D and 2-D methods for estimating discharge capacity of straight compound channels. Advances in Engineering Software, 41, 120-129.

WEBER J.F. and MENÉNDEZ A.N., 2004: Performance of lateral velocity distribution models for compound channel sections. In: Greco, Carravetta and Della Morte (eds.) River Flow 2004, Taylor \& Francis Group, London Wilson, C.A.M.E., Yagci, O.

Received 21 July 2010 Accepted 12 April 2011 